their metabolic response to the trauma, patients who have only just undergone surgery (our control group) may not be considered as representative of patients who require jejunostomy feeding. However, since many of the latter have undergone surgery recently, and the metabolic response to surgery is often prolonged by postoperative complications (Moore and Ball, 1952) the two situations are probably not so different.

In our control group positive sodium balance was maintained -no doubt aided by postoperative sodium retention-and positive potassium balance and normal urine volumes were achieved despite the tendency to $K$ loss and water retention due to the metabolic response to surgery. However, the characteristic postoperative negative nitrogen balance, though substantially reduced, was not reversed by the feed. (These results have been published in detail elsewhere-Hindmarsh and Clark, 1973.) Intestinal stasis may have contributed to the reduced fat excretion by promoting storage of faeces in the colon; however, most patients had normal bowel action by day 4 or 5 , so any significant degree of fat malabsorption should have been detected.

We are not, of course, recommending that all patients who have undergone vagotomy and pyloroplasty should be fed by jejunostomy: most of them recover equally well without such measures.

The patients in our fistula group achieved adequate urine volumes and satisfactory sodium, potassium, and nitrogen balances. Two had fairly severe steatorrhoea, probably due to loss of pancreatic lipase and bile salts in the fistula drainage, but much of the administered fat ( $105 \mathrm{~g}$ daily) was absorbed; had medium-chain triglyceride been substituted absorption might have been greater. Though most of the feed's total nitrogen was whole protein it appeared to be hydrolysed and absorbed. Normal amounts of nitrogen were excreted in the faeces despite sizable losses of gastric and pancreatic juices by all the patients, so it is unlikely that any had gross protein malabsorption. However, mild protein malabsorption cannot be excluded. Protein not absorbed by the small intestine may have been digested by proteolytic bacteria in the large intestine, and the resultant nitrogen derivatives absorbed, resulting in normal faecal nitrogen excretion.

Masterton et al. (1963) stated that jejunostomy feeds should have an osmolarity similar to that of body fluids (about 300 $\mathrm{mOsm} / 1$.), but no patient receiving our feed (about $550 \mathrm{mOsm} / 1$.) had diarrhoea. We used glucose as the added carbohydrate, since the severe diarrhoea that developed in those to whom we gave Masterton's diets (table IV) could have been due to intolerance of the large lactose content (Peaston, 1967).

We thank Miss Norma Lauder, departmental dietician, for her valuable help; the Misses A. Brent and J. Wright, ward sisters, for their enthusiastic co-operation; and Miss Ursula Matthews and her staff in the Editorial Service to the Faculty of Medicine, Dalhousie University, for help with the manuscript. We are indebted to the Endowment Fund of the United Sheffield Hospitals for financial support and to B.D.H. Pharmaceuticals Ltd. for supplies of Prosparol.

Requests for reprints should be addressed to: Dr. J. T. Hindmarsh, The Royal Infirmary, Sheffield.

\section{References}

Boles, T., jun., and Zollinger, R. M. (1952). Archives of Surgery, 65, 358 Calloway, D. H., and Spector, H. (1954). American fournal of Clinical

Case, C. T., Zollinger, R. M., McMullen, C. H., and Brown, J. B. (1949). Surgery, 26, 364 .

Co Tui, et al. (1944). Annals of Surgery, 120, 99.

Davidson, S., and Passmore, R. (1969). In Human Nutrition and Dietetics, 4th edn., p. 85. Edinburgh, Livingstone.

Food and Nutrition Board, National Academy of Sciences-National Research Council (U.S.A.) (1968). Recommended Dietary Allowances, 7th rev. edn., p. 102, Publ. No. 1694. National Academy of Sciences Washington, D.C.

Hindmarsh, J. T., and Clark, R. G. (1973). British fournal of Surgery. $60,589$.

Jones, C. R. (1916). Surgery, Gynecology and Obstetrics, 22, 236.

Jones, C., and McIntosh, N. (1973). Lancet, 1, 156.

Kay, A. W. (1964). British Medical fournal, 1, 822

Keele, C. A., and Neil, E. (1961). In Samson Wright's Applied Physiology, 10th edn., p. 442. London, Oxford University Press.

Kinney, J. M. (1960). Bulletin of the Nerv York Academy of Medicine, 36, 617 .

Le Quesne, L. P. (1955). In Fluid Balance in Surgical Practice, p. 11 Chicago, Year Book Publishers.

Levey, S., Czarnecki, N., Krieger, H., and Abbott, W. E. (1960). Federation Proceedings, 19, 325.

Masterton, J. P., Dudley, H. A. F., and MacRae, S. (1963). British Medical

Fournal, 2, 909 .
Moore, F. D., and Ball, M. R. (1952). Metabolic Response to Surgery, p. 80, 145. Springfield, Illinois, Thomas.

Pareira, M. D., and Heeb, M. A. (1958). Archives of Surgery, 77, 851.

Peaston, M. J. T. (1967). Postgraduate Medical fournal, 43, 317.

Ravdin, I. S., Stengel, A., jun., and Prushankin, M. (1940). Fournal of the American Medical Association, 114, 107.

Rose, W. C. (1957). Nutrition Abstracts and Reviews, 27, 631.

van de Kamer, J. H., Huinink, H. B., and Weyers, H. A. (1949). Fournal of Biological Chemistry, 177, 347.

Varley, H. (1967). In Practical Clinical Biochemistry, 4th edn., p. 194, 491. London Heinemann.

Wilkinson, A. W., Billing, B. H., Nagy, G., and Stewart, C. P. (1950). Lancet, 1,533 .

Wilmore, D. W., and Dudrick, S. J. (1969). Archives of Surgery, 98, 256.

\title{
Measles and Other Virus-specific Immunoglobulins in Multiple Sclerosis
}

\author{
MARGARET HAIRE, K. B. FRASER, J. H. D. MILLAR
}

British Medical fournal, 1973, 3, 612-615

\section{Summary}

Immunoglobulins $M$ and $G$ specific for measles, herpes simplex, and rubella viruses were assayed by the fluorescent antibody method in sera and cerebrospinal fluids

\footnotetext{
Department of Microbiology, The Queen's University of Belfast, Belfast BT12 6BN

MARGARET HAIRE, M.D., M.R.C.PATH., Senior Research Fellow

K. B. FRASER, M.D., D.SC., Professor of Microbiology

Department of Neurology, Royal Victoria Hospital, Belfast BT12 6BN

J. H. D. MILLAR, M.D., F.R.C.P., Consultant Neurologist
}

(C.S.F.) obtained simultaneously from 30 patients with multiple sclerosis, 30 patients with other neurological diseases, and 30 "normal" control subjects. Sera of 11 out of 30 patients with multiple sclerosis had IgM which reacted specifically with measles virus-infected cells, compared with 2 out of 30 of the patients with other neurological diseases and none of the 30 normal controls. Virus-specific IgM was not found in C.S.F. by this method.

The geometric mean titre of measles virus-specific IgG in serum was significantly higher in the multiple sclerosis group than in either control group, and while IgG specific for all three viruses was found in C.S.F., suggesting transfer across the blood-brain barrier, measles IgG predominated. 
There seems a possibility that measles virus may have affected the blood-brain barrier and so initiated the pathogenic processes in multiple sclerosis.

\section{Introduction}

Since first reporting the presence of measles virus-specific immunoglobulin $M$ in the sera of a few patients with multiple sclerosis (Millar et al., 1971) we have extended our observations by assaying virus-specific immunoglobulins $M$ and $G$ (IgM and IgG) in the sera and cerebrospinal fluids (C.S.F.) of multiple sclerosis patients and control subjects.

In summary, we have confirmed that IgM specific for measles virus-infected cells is present in sera from some multiple sclerosis patients, the titre of measles-specific IgG in serum of patients with the disease is increased in conformity with the antibcdy increases reported by other workers (Brody et al., 1972), and measles and herpes simplex antibodies in C.S.F. were of the IgG class and not IgM (Haire et al., 1973).

We now present a third survey which is more complete in two respects than preceding ones, in that serum and C.S.F. have been obtained from all individual patients, and the three series of 30 patients each provide "normal" and abnormal controls for the test group. Another advantage is that the use of unfixed, infected cells for assaying virus-specific IgM has removed difficulties of recognizing primary IgM staining (Shirodaria et al., 1973) by eliminating intracellular non-specific staining which is a problem with multiple sclerosis sera (Millar et al., 1971).

In this survey antibodies to cells infected with measles virus, herpes simplex virus, and to rubella virus have been studied because of their similar titres of virus-specific IgG in sera when tested by the fluorescent antibody technique (Haire et al., 1973). Tests on C.S.F. were included because our previous survey (Haire et al., 1973) had shown measles antibody in the C.S.F. of 16 out of 25 multiple sclerosis patients and in none of 17 in a normal control group, and Brown and his colleagues (1971) had shown a significantly higher incidence of measles antibody in the C.S.F. of 119 multiple sclerosis patients compared with 112 patients with other nervous diseases.

\section{Patients, Materials, and Methods}

C.S.F. and blood were obtained at the same time from 30 consecutive patients with multiple sclerosis, 30 patients suffering from other neurological diseases, and 30 patients undergoing myelography for suspected prolapsed intervertebral disc. The last group form our "normal control" group. The neurological disease group includes patients with the following diagnoses: six cerebrovascular disease, five dementia, four motor neurone disease, four neurosyphilis, three polyneuritis, two cervical spondylosis, two secondary carcinoma (brain), two syringomyelia, one hereditary ataxia, and one spinal meningioma. The sex distribution of the patients in the three groups is similar, but the neurological control group differs from the others in respect of age because of a higher incidence of patients over 50 vears of age.

Specimens were stored at $-20^{\circ} \mathrm{C}$ and were tested under code. Indirect immunofluorescent techniques as already described (Haire and Hadden, 1970; Millar et al., 1971; Haire et al., 1973) were used to detect and titrate measles, herpes simplex, and rubella virus-specific IgM and IgG antibodies. In addition to acetone-fixed cells, unfixed preparations of virus-infected cells were used to test for virus-specific IgM at the cell surface. Specificity of staining was checked by absorption with semipurified virus, and cross-reactions with normal and multiple sclerosis brain tissue were checked by absorption of sera with a homogenate of the appropriate material. Staining by specific IgM was similar with both measles virus-infected Vero cells and measles virus-infected HEp2-cells, but none was seen in uninfected cells.
We use the term IgM or IgG staining for convenience to mean the detection of virus-specific antibody of the relevant class.

While the technique we have used is not the most sensitive, it has the advantage of being capable of detecting all bound antibody, and it can also be used to assay virus-specific antibody in different immunoglobulin classes.

\section{Results}

\section{LABORATORY FINDINGS}

Virus-specific IgM was found only in serum but virus-specific IgG was present in serum and C.S.F. The incidence of virusspecific IgM in sera is shown in table I, and table II shows the incidence of virus-specific IgG in C.S.F. and the geometric mean titre of virus-specific IgG in sera. Because of the scarcity of C.S.F. the series of rubella tests is not complete.

TABLE I-Number of Sera showing IgM Staining of Measles and Herpes Simplex Virus-infected HEp2 Cells and Rubella Virus-infected BHK21 Cells

\begin{tabular}{|c|c|c|c|c|}
\hline \multirow{2}{*}{\multicolumn{2}{|c|}{ Cells Infected with }} & \multicolumn{3}{|c|}{ Clinical Condition } \\
\hline & & $\begin{array}{l}\text { Multiple } \\
\text { Sclerosis }\end{array}$ & $\begin{array}{c}\text { Other Neurological } \\
\text { Diseases }\end{array}$ & \multirow{2}{*}{$\begin{array}{c}\begin{array}{c}\text { Normal } \\
\text { Control }\end{array} \\
0 \\
0 \\
0 \neq\end{array}$} \\
\hline $\begin{array}{l}\text { Measles virus } \\
\text { Herpes simplex virus } \\
\text { Rubella virus }\end{array}$ & $\begin{array}{l}\cdots \\
\therefore\end{array}$ & $\begin{array}{l}11 \\
1 \\
0+\end{array}$ & $\begin{array}{ll}2 & \left(1^{*}\right) \\
1 & \\
0 & \\
\end{array}$ & \\
\hline No. tested & .. & 30 & 30 & 30 \\
\hline
\end{tabular}

* Patients had measles IgG in C.S.F.

†wenty-eight tested.
†Twenty-nine tested.

TABLE II-Incidence of Measles, Herpes Simplex, and Rubella IgG in C.S.F. and Geometric Mean Titres (G.M.T.) of IgG Antibody in Corresponding Sera

\begin{tabular}{|c|c|c|c|c|c|c|}
\hline \multirow{3}{*}{ IgG Antibody to } & \multicolumn{6}{|c|}{ Clinical Condition } \\
\hline & \multicolumn{2}{|c|}{$\begin{array}{l}\text { Multiple } \\
\text { Sclerosis }\end{array}$} & \multicolumn{2}{|c|}{$\begin{array}{l}\text { Other } \\
\text { Neurological } \\
\text { Diseases }\end{array}$} & \multicolumn{2}{|c|}{$\begin{array}{l}\text { Normal } \\
\text { Controls }\end{array}$} \\
\hline & $\begin{array}{l}\text { IgG } \\
\text { C.S.F. }\end{array}$ & $\begin{array}{l}\text { IgG } \\
\text { Serum } \\
\text { G.M.T. }\end{array}$ & $\begin{array}{l}\text { IgG } \\
\text { C.S.F. }\end{array}$ & $\begin{array}{l}\text { IgG } \\
\text { Serum } \\
\text { G.M.T. }\end{array}$ & $\begin{array}{l}\text { IgG } \\
\text { C.S.F. }\end{array}$ & $\begin{array}{l}\text { IgG } \\
\text { Serum } \\
\text { G.M.T. }\end{array}$ \\
\hline $\begin{array}{l}\text { Measles virus } \\
\text { Herpes simplex virus } \\
\text { Rubella virus } ₫\end{array}$ & $\begin{array}{c}19 / 30 \\
11 / 30^{*} \\
6 / 18\end{array}$ & $\begin{array}{l}40 \cdot 0 \\
24 \cdot 7 \\
21 \cdot 9\end{array}$ & $\begin{array}{l}2 / 30 \\
7 / 30 \dagger \\
2 / 21\end{array}$ & $\begin{array}{l}13 \cdot 4 \\
30 \cdot 8 \\
14 \cdot 0\end{array}$ & $\begin{array}{l}1 / 30 \\
2 / 30 \ddagger \\
1 / 16\end{array}$ & $\begin{array}{l}20 \cdot 0 \\
17 \cdot 6 \\
13 \cdot 6\end{array}$ \\
\hline
\end{tabular}

About one multiple sclerosis patient in three had measles virus-specific $\operatorname{IgM}$ in serum as compared with 1 in 15 of the other neurological diseases and none out of 30 normal controls. The presence of measles virus-specific IgM in serum is associated with a slightly higher titre of virus-specific IgG in the serum than is found in serum without measles IgM $(1 / 54.8$ as against $1 / 33.3$ ), but the difference is not statistically significant.

It will be seen from table II that C.S.F. of multiple sclerosis patients contains IgG specific for all three test viruses, but measles-specific IgG occurs most often. It should be stated in addition that measles-specific IgG in C.S.F. always gave bright staining, capable of being titrated at a range from 1 in 5 to 1 in 20 in half the patients; staining by IgG specific for herpes simplex and rubella viruses was usually much fainter and was only positive in undiluted C.S.F.

The titre of measles antibody is significantly higher in the multiple sclerosis group compared with either of the control groups (multiple sclerosis group versus neurological control group: $\chi^{2}, 13.43$; D.F., 1 ; significant at $P<0.001$ : multiple sclerosis group versus normal control group: $\chi^{2}, 5 \cdot 69$; D.F., 1 ; significant at $P<0.05$ ). The differences shown between the titres of herpes simplex and rubella antibody in the three groups 
in the present survey are not statistically significant. This finding differs from our previous survey in which herpes simplex virus-specific IgG was significantly higher in multiple sclerosis than in normal controls (Haire et al., 1973), an inconsistency which has been the experience of other workers (Brody et al., 1972).

There is an apparent correlation between the presence of virus-specific IgG in the C.S.F. and the titre of virus-specific IgG in the sera, as judged by geometric mean titres (see fig.), but a greater number of observations will be required in order to assess the significance.

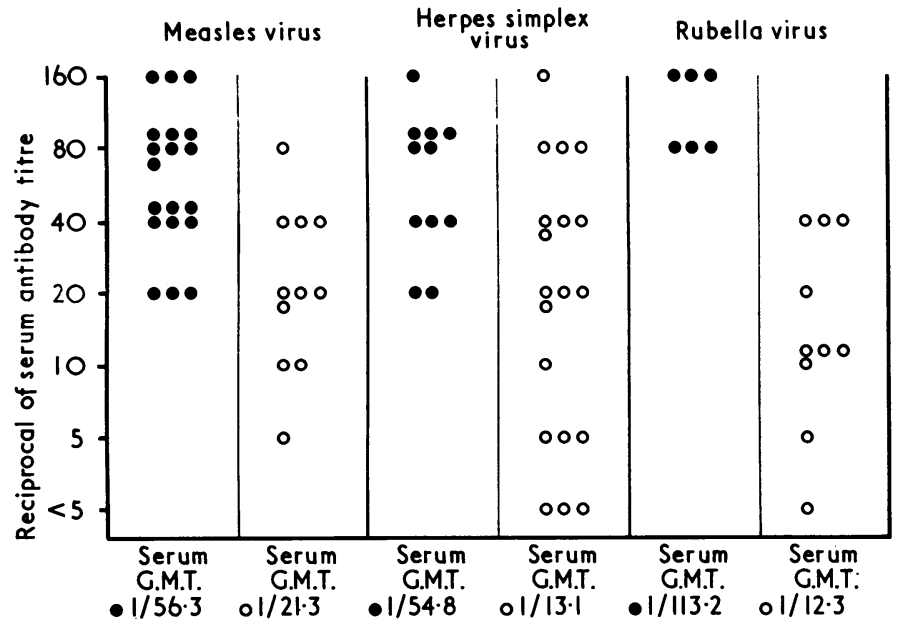
Distribution of virus-specific IgG serum titres in relation to presence or
absence of same antibody in C.S.F. $=$ C.S.F. positive. $O=$ C.S.F. negative. G.M.T. = Geometric mean titre.

In such a small survey we could not establish a positive correlation between the presence of measles IgG in C.S.F. and measles IgM in serum (table I).

\section{CLINICAL NOTES}

The neurological control patient who had both measles and herpes simplex IgM in serum suffered from cerebrovascular disease. Another, who had measles $\operatorname{IgM}$ in serum and measles IgG in C.S.F., had been treated for general paralysis of the insane 17 years previously. The other neurological control who had measles IgG in C.S.F. had a secondary tumour in the brain stem and he also had had an unexplained morbilliform rash two weeks before lumbar puncture.

The patient in the normal control group who had measles IgG in C.S.F. had been investigated for sciatica. The myelogram was normal apart from a slight disc protrusion at L4,5 and further questioning revealed that she had had weakness and stiffness of the legs for two years. On examination a spastic paraparesis with extensor plantar responses was found.

\section{Discussion}

The presence of IgM specific for measles virus-infected cells in a proportion of patients with multiple sclerosis has been confirmed in the present survey and the observation must now be regarded as a relevant characteristic of the antibody response in the disease. We believe that the proportion $11 / 30$ is nearer to the true incidence of measles-specific IgM, since the very low titres of a previous survey, in which the advantages of unfixed infected cells as antigen had not been discovered, invalidated absorption results which were designed to distinguish between primary and secondary IgM staining.
The relation between measles-specific IgM and IgG is, presumably, that found in normal antigenic stimulation, IgM appearing early and remaining while antigenic stimulation continues. If so, continuous antigenic stimulation by measles virus, or an antigen related to it, is implied in patients with multiple sclerosis. Here we assume that the IgM of multiple sclerosis patients is staining the same antigenic determinants as the IgM of measles patients, a point which remains to be formally proved. The use of unfixed tissue shows that the determinants to which IgM is fixed are at the cell surface, and are more likely to be related to haemagglutinin or haemolysin than to the internal components of measles virus, though antibodies to all three have been described in multiple sclerosis (Salmi et al., 1972). If there is a cross-reaction between measles and some unrecognized persisting antigen it does not seem to reside in normal brain or in the brains of patients with multiple sclerosis, as judged by our failure to remove the measlesspecific IgM by absorption with brain tissues.

There is no evidence of measles virus-specific IgM in C.S.F. as we found in cases of subacute sclerosing panencephalitis (Connolly et al., 1971). Thus there is no justification for postulating from present data that measles virus persists intracerebrally as it does in subacute sclerosing panencephalitis (Connolly et al., 1967).

How much of the immunoglobulin in C.S.F. and the central nervous system is measles specific is not known, but, if the measles virus-specific globulin influences the neurological lesions of multiple sclerosis directly, it ought to be found in the IgG which is known to surround multiple sclerosis plaques in the brain (Simpson et al., 1969).

The presence of IgG specific for several viruses is strong evidence for leakage across the capillaries of the blood-brain barrier. Persistent leakage of this sort could well result in the pathogenic mechanism postulated for the disease by Lumsden (1971), and it is a recognized feature of other immunopathogenic processes.

In conclusion, we believe that the case for some specific relation between measles virus and multiple sclerosis is strengthened by our findings. The relation, as deduced from all our surveys, seems to consist of a very slight hyperactivity of IgG synthesis, more specific for measles virus than for other enveloped viruses; of a distinctly increased prevalence in multiple sclerosis patients of low titre IgM specific for the membranes of measles virus-infected cells; and of a tendency, which may be secondary to increased titre, for measles virus-specific IgG to predominate over other virus IgG in the C.S.F. of patients with the disorder.

Whether the immunological reactivity represents a continuous specific antigenic stimulation or whether it represents some abnormality of the cellular controls which would normally have damped down the synthesis of measles antibody remains to be discovered.

We wish to thank Dr. H. J. L. Withers and the orthopaedic surgeons at the Musgrave Park Hospital, Belfast, who obtained specimens of serum and C.S.F. from the "normal control" group of patients. Dr. J. S. McCann, Consultant Venereologist, Royal Victoria Hospital, Belfast, kindly supplied specimens from patients with neurosyphilis. Miss Elizabeth $\mathbf{M}$. Henderson gave valuable technical help.

This work is supported by a grant from the Medical Research Council, and the Multiple Sclerosis Society of Great Britain and Northern I reland.

\section{References}

Brody, J. A., Sever, J. L., Edgar, Anne, and McNew, Jane (1972). Neurology (Minneapolis), 22, 492.

Brown, P., Cathiala, Francoise, Gajdusek, D. C., and Gibbs, C. J. (1971) Proceedings of the Society for Experimental Biology and Medicine, 137, 956.

Connolly, J. H., Allen, Ingrid V., Hurwitz, L. J., and Millar, J. H. D. (1967). Lancet, 1, 542.

Connolly, J. H., Haire, Margaret, and Hadden, Diana S. M. (1971). British Medical fournal, 1, 23. 
Haire, Margaret, Fraser, K. B., and Millar, J. H. D. (1973). Clinical and Experimental Immunology, 14, 409.

Haire, Margaret, and Hadden, Diana S. M. (1970). British Medical fournal, 3, 130 .

Lumsden, C. E. (1971). Brain Research, 28, 365.

Millar, J. H. D., et al. (1971). British Medical fournal, 2, 378.
Salmi, A. A., Norrby, E., and Panelius, M. (1972). Infection and Immunity, 6, 248

Shirodaria, P. V., Fraser, K. B., and Stanford, F. (1973). Annals of the Rheumatic Diseases, 32,53

Simpson, J. F., Tourtellote, W. W., Kokman, E., Parker, J. A., and Itabashi, H. H. (1969). Archives of Neurology, 20, 373.

\section{PRELIMINARY COMMUNICATIONS}

\section{New and Simple Test of Nerve Function in Hand}

\author{
SEAMUS O'RIAIN
}

British Medical fournal, 1973, 3, 615-616

\section{Summary}

A simple objective test of innervation and regeneration of sensory nerves in the hand by immersion in warm water is described. The test results are shown to correpond to operation findings.

\section{Introduction}

Moberg (1958) recently focused our attention on the type of sensation in our fingertips which enables us to recognize unseen objects by touch alone. Sensation in the hand has been tested by such methods as the coin test (Seddon, 1954) and two-point discrimination (Weber, 1835), which are subjective tests and therefore depend on the patient's co-operation and intelligence. Moberg (1958) devised an objective test depending on the sweating of the skin of the fingers-the ninhydrin fingerprint method-and with it he was able to show objectively which parts of the skin had intact sensation and which parts were defective.

\section{Patients and Method}

Over two years ago the mother of a child who had had a nerve repair in the hand reported that she noticed at bath time the skin of the denervated fingers did not "shrivel" like the normal fingers, and that after repair shrivelling of the skin returned progressively from palm to tips.

Since then a number of patients have been tested by immersing their hands and forearms in water at approximately $40^{\circ} \mathrm{C}$ for a period of 30 minutes and the normal shrivelling of the skin of their fingers has been observed. It has been noted that after this procedure denervated skin does not shrivel; it remains smooth.

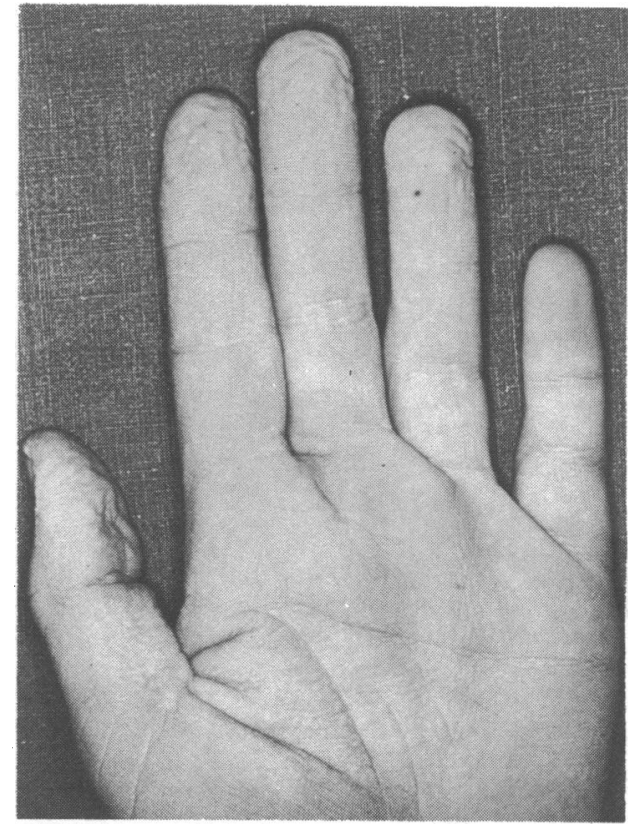

FIG. 1-Patient with ulnar nerve lesion. Skin of little finger remained smooth after immersion in water.

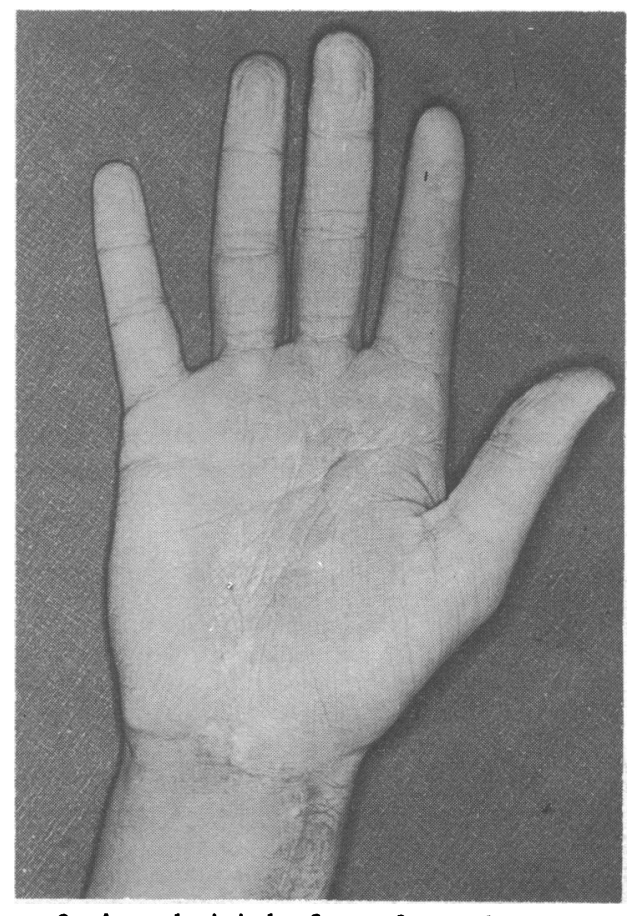

FIG. 2-Anaesthetic index finger after tendon graft and multiple nerve repairs. 